\title{
The Influence Of Perception On Purchasing Decision Of Soy Sauce Sachet In Rural And Urban Area
}

\author{
Hazrina Rachmawati* \\ Department of Family and Consumer Sciences. \\ Faculty of Human Ecology \\ Bogor Agricultural University \\ *Corresponding author: hazrinarachmawati@gmail.com \\ Istiqlaliyah Muflikhati \\ Department of Family and Consumer \\ Sciences. Faculty of Human Ecology \\ Bogor Agricultural University
}

\begin{abstract}
Nowadays. the soy sauce is sold in various of sizes plastic package from a large size to sachet. It is. therefore. very important to analyze the factors that influence the purchasing decision of soy sauce sachet. The study was conducted in Kebon Kalapa Subdistrict. Bogor District as an urban area and Galuga Subdistrict. Bogor Disctrict as a rural area. One hundred and seventy-four households became the subject of the study and they were chosen by simple random sampling. The data were analyzed by using Chi-square. Independent sample t-test. Pearson correlation. and logistic regression. The result of the study showed that in rural area. the number of family members and price perception on purchasing decisions toward the soy sauce sachet influenced significantly. Overall. the price perception significantly influenced the purchasing decisions toward the soy sauce sachet.
\end{abstract}

Keywords: perception, purchasing behavior, purchasing decision, soy sauce package

\begin{abstract}
Abstrak. Saat ini kecap dijual dalam kemasan plastik berbagai ukuran dari ukuran besar sampai kemasan sachet sehingga. pentingnya untuk menganalisis faktor yang berpengaruh terhadap keputusan pembelian kecap kemasan sachet. salah satunya adalah persepsi. Penelitian dilakukan di Kelurahan Kebon Kalapa. Kota Bogor sebagai wilayah perkotaan dan Desa Galuga. Kabupaten Bogor sebagai wilayah pedesaan. Contoh dari penelitian ini adalah 147 rumah tangga. Penentuan contoh diambil secara simple random sampling. Analisis data yang digunakan adalah Chi-square. Independent sample t-test. uji korelasi Pearson. dan uji regresi logistik. Berdasarkan hasil uji di perkotaan. jumlah anggota keluarga dan persepsi harga berpengaruh signifikan terhadap keputusan pembelian kecap kemasan sachet. Secara keseluruhan persepsi harga berpengaruh signifikan terhadap keputusan pembelian kecap kemasan sachet.
\end{abstract}

Kata kunci: perilaku pembelian, persepsi, kecap kemasan, keputusan pembelian 


\section{Introduction}

Nowadays. the development of plastic usage in Indonesia is increasing which has an impact on the increase of plastic waste. The Ministry of Environment and Forestry has a target to reduce plastic waste of more than 1.9 million tons by 2019. Indonesia's total waste in 2019 is estimated to reach 68 million tons. 14 percent of which is plastic packaging waste. Vice Chairman of the Aromatic and Plastics Olefin Association of Indonesia (Inaplas) stated that there has been a trend of plastic use for food products. National plastic consumption is dominated in the form of packaging which reaches 65 percent. while 35 percent is used by large industries for the manufacture of household appliances.

Packaging is a protector of goods. both ordinary goods and industrial products (Priyogutomo 2011). Shopping places. like stalls. shops. and markets provide food packaging with various sizes. one of which is soy sauce. Ketchup is one of the foods packaged using both plastic and bottles that tend to be available in every household (Dewi et al.. 2013). Ketchup was one of the food products consumed by every household with the average consumption of soy sauce in Indonesia during the period of 2002-2012. reaching $0.633 \mathrm{~kg} / \mathrm{cap} / \mathrm{year}$ compared to the consumption of other soybean products such as tauco and oncom (Pusdatin 2003). This shows that the consumption of soy sauce in Indonesia is quite high. The soy sauce product that consumers prefer is a small size soy sauce product of $<200 \mathrm{ml}$ with plastic packaging (Dewi et al.. 2013). According to Ruwani et al. (2014). small size packaging products are chosen by many consumers because they are considered more practical.

Purchasing decisions involve consumer decisions about what to buy. whether to buy or not. when to buy. where to buy. and how to pay for it. Consumer decision process to buy or not begins with the introduction of needs. information search. alternative evaluation. option alternative determination. which ultimately determine whether products are purchased or not (Sumarwan 2011). Factors influencing purchasing decisions are internal (age. economic status. occupation. lifestyle) and external (product attributes. family influences) factors (Soegiono 2010). According to Schiffman and Kanuk (2008). the process of decision-making is influenced by psychological fields that exist in selfmotivation. perception. learning. personality. and attitude. In addition. psychological factors determine acceptance and interaction with the environment and influence on decisions in which consist of perceptions. motivations. learning. beliefs. and attitudes (Lamb et al. in Priyogutomo 2011).

Perception is the process of choosing. organizing. and interpreting sensations to be meaningful (Solomon 2001). The perception of consumers living in urban and rural areas will be different. This is because the exposure to stimuli obtained and the levels of sensation are different (Sumarwan 2011). Under the same or different conditions. the perception of each person to a product varies. this is because of the process of perception performed. such as selective attention. selective distortion. and selective retention of various stimuli (Kotler and Keller 2016). Perception in this research is divided into perception of price. usability. availability. and risk. 
One's perception is influenced by three influences. namely characteristic of stimuli or stimuli. stimuli relationship with its surroundings. and condition in self (Setiadi 2010). Characteristics of stimuli. such as attributes of a product affect consumer perceptions (Zuhdi and Supardi 2009). In addition. the socio-economic characteristics of consumers. such as age. sex. and education have an influence on perception (Kariyawasan et al.. 2006). According to Samosir and Prayoga (2015) perceptions affect the purchase decision. Consumers often decide to purchase a product based on their perception of the product. Consumer receives all stimuli through the five senses. but not all stimuli are stored in the consumer's memory. This happens because consumers do information processing. Consumer processing information occurs when one of the five senses consumers receive input in the form of stimulus (Sumarwan 2011).

Packaging sizes have a huge role in purchasing decisions (Patel and Bhatt 2015). Household purchasing decisions are influenced by income earned (Leibtag and Kaufman 2003) and public perceptions that are influenced by product attributes (Zuhdi and Supardi 2009). According to Patel and Bhatt (2015). people with low incomes will buy small size or sachet products. which actually they pay more for those small size products. In this research. ketchup packaging sachet is soy sauce - household consumption product packed with volume $14 \mathrm{ml}$ and $22 \mathrm{ml}$. Based on the description. this study aimed to analyze the influence of perceptions on the purchase decision of soy sauce packaging in urban and rural sachets.

\section{Method}

The research was conducted by cross sectional study design with survey method. The research was conducted in RW 02 and RW 05. Kebon Kalapa Subdistrict. Bogor Tengah Sub-district. Bogor City representing urban area. and in RW 01 and RW 02. Galuga Village. Cibungbulang District. Bogor Regency representing rural area. The time of the study was conducted from October to December 2015.

The population of this research is household taken with simple random sampling technique. The number of respondents is 147 households consisting of 73 respondents in urban areas and 74 respondents in rural areas. Respondents from this study were the main determinants of decision making of soy sauce in the household. Selection of location by purposive is used to determine Bogor District. subdistrict. village. and village. While the determination of the pillars of citizens and households was done randomly.

The data collected in this research were primary data. namely (1) individual characteristic including age. education duration. occupation. (2) family characteristics including family members and per capita income. (3) buying behavior of soy sauce including packaging type and volume of soy sauce. purchasing frequency and place of purchase. (4) individual perception of sachet packaging. (5) purchase decision of soy sauce packaging sachet. and (6) reason for purchasing soy sache packaging. Primary data was collected by using in-depth interview method using questionnaire.

The perceptual instrument on the sachet packaging was modified from Kittilertpaisan and Chanchitpreecha (2013). Questionnaires that measure perceptions amount to 12 statement items. The types of perceptions analyzed were 
price perception. usability perception. perception of availability. and risk perception. The scale used was the ordina likert scale with four scales. i.e. 1 "strongly disagree" to 4 "strongly agree" (Sappaile 2007). The reliability of questionnaire was 0.74 . This indicates that the instrument used was reliable. Likert-scale measurements on perceptual approval are further analyzed by using top two boxes and combining individual responses "1 (strongly disagree) and 2 (disagree) to 0 (disagree)" and "3 (agree) and 4 (very Agree) to 1 (agree)". Perceptions of sachet packaging were categorized based on perceptual index. negative. less than 50.00 and which were positively greater than or equal to 50.00 .

The instruments of buying behaviour were open questions asking about packaging type and volume of soy sauce. purchase frequency. expenditure. and place of purchase. The reason for purchasing soy sauce packaging sachet was measured using a modified questionnaire from Marketing and Consumer Research (Sumarwan et al.. 2013). in the form of fifteen reasons for the purchase of soy sachets with the form of "disagree" 0 and "agree" score 1 . The ladder buying the soy sachets packet is analyzed on the reason of the purchase. Categorization of decision data of the purchase of soy sauce packaging sachet was done by grouping households who buy and do not buy soy sachet packaging. if they had bought then denoted by the number 1 and if they had not buy denoted by the number 0 .

The data were obtained were then processed by descriptive and inferencing analysis. Descriptive analysis was used to see the distribution of individuals based on individual and family characteristics. perceptions. and the reasons for the purchase of soy sachets. In addition. descriptive analysis was used to view the distribution of individuals based on purchasing behavior and decisions in the purchase of soy sachets. Inferencia analysis which used Chi-square test was used to analyze the difference of the type and volume of soy sauce. the place of purchase of soy sauce. the work. and the decision of the purchase of soy sauce in urban and rural packaging. The Independent sample t-test was used to examine the differences in individual and family characteristics. the frequency of soy sauce purchase. soy sauce expenditure. and to analyze differences in perceptions on the purchase of sachet packs in urban and rural areas. Pearson's correlation was used to look at the relationship of individual and family characteristics to the perception of sachet packaging. Logistic regression was used to examine the effect of individual characteristics. family characteristics. and individual perceptions on purchasing decisions of soy sachets in urban. rural. and urban and rural settings.

\section{Result and Discussion}

\section{Individual and Family Characteristics}

The average age of respondents in urban areas was 45.63 years and the age of individuals in rural areas was 40.16 years. according to Sumarwan (2011) the age range of individuals in urban and rural areas is in the middle-aged life cycle (36-50 years). The consumer's need for a product was influenced by its age. The average level of individual urban education was at the junior secondary level. while in rural areas at the primary level. this is consistent with the research of Sebataraja et al. (2015) that the duration of community education in rural areas is lower than that in urban communities. 
Table 1 Descriptive statistics. minimum values. maximum values. mean. and differential test of individual and family characteristics by region

\begin{tabular}{|c|c|c|c|c|c|c|c|}
\hline \multirow{2}{*}{ Variable } & \multicolumn{3}{|c|}{ Urban $(n=73)$} & \multicolumn{3}{|c|}{ Rural $(n=74)$} & \multirow[t]{2}{*}{ p-value } \\
\hline & Min & Max & Mean & Min & Max & Mean & \\
\hline Individual Characteristic & & & & & & & \\
\hline Individual age (year) & 23 & 74 & 45.63 & 18 & 80 & 40.16 & $0.013^{*}$ \\
\hline $\begin{array}{l}\text { Individual education } \\
\text { lenght (year) }\end{array}$ & 0 & 16 & 9.01 & 0 & 16 & 6.85 & $0.000 * *$ \\
\hline $\begin{array}{l}\text { Family Characteristic } \\
\text { Number of family } \\
\text { member (person) }\end{array}$ & 1 & 9 & 4.25 & 1 & 10 & 4.28 & 0.895 \\
\hline $\begin{array}{l}\text { Total income (IDR } \\
000 / \text { month) }\end{array}$ & 50 & $\begin{array}{r}26.20 \\
0\end{array}$ & $\begin{array}{r}3.487 .1 \\
9\end{array}$ & 100 & $\begin{array}{r}50.00 \\
0\end{array}$ & $\begin{array}{r}3.769 .9 \\
8\end{array}$ & 0.772 \\
\hline $\begin{array}{l}\text { Per capita income } \\
\text { (IDR 000/month) }\end{array}$ & 33 & 8.733 & 905.52 & 10 & 1.250 & 923.38 & 0.943 \\
\hline
\end{tabular}

Explanation : *) significant at $\mathrm{p}$-value $<0.05 ; * *)$ significant at $\mathrm{p}$-value $<0.01$

The average number of family members is a small family. that is. the number of family members which is less or equal to four people (BKKBN). The average individual per capita income in urban and rural areas was above the poverty line according to BPS West Java Province in September of 2015. in which the urban poverty line limit was Rp318.297. and rural poverty line limit was Rp319.228. As reported. the number of the main decision makers of sack packaging purchases in urban and rural areas was respectively wives - 97.27 percent. children - 2.04 percent. and mothers - only 0.68 percent. Based on income pattern. the largest individuals in urban have monthly income pattern $(52.00 \%)$. daily and monthly $(26.67 \%)$. while in rural areas the largest proportion is daily income (30.67\%) and monthly (29.33\%). Different test results between individual and family characteristics in urban and rural areas showed significant differences in individual age and length of individual education.

\section{Perception of Sachet Packaging}

Perceptions in question include the perception of price. usage. availability. and risk. Price perception becomes a consumer judgement of the comparative amount of sacrifice to that of products and services (Zeithaml 1988). The percentage of individuals on price perceptions that the price becomes the most important thing in the purchase of sachet packaging is higher than that which has the perception that the price is not important. This is because the price of soy sauce packaging sachet is cheaper than other types of soy sauce packaging (Dewi et al.. 2013). so in making the purchase. the money is sacrificed a little. This is consistent with Setiadi's (2010) statement that a person's perceptions will be influenced by characteristics of stimuli or product attributes such as price and size. In addition. consumers often perceive risk in making product selection decisions. one of which is financial risk (Solomon 2001). Types of packaging sauce purchased by urban individuals $(17.80 \%)$ and rural $(29.72 \%)$ were soy sachets. In Sukma and Baihaqi (2013) research. individuals perceive affordable 
prices because the products are available in various sizes. i.e.. small to large packaging sizes. small size products have low prices which are so affordable.

Perceptions of usefulness in this study is the ease to use products that have been packaged. The practicality and variation of soy packaging volume is a technology developed to facilitate consumers in their use. Almost all individuals in urban (91.80\%) and in rural areas $(93.20 \%)$ have a perception that the use of sachet packaging is more practical. This is in accordance with research Sugiyanto et al. (2014). consumers declare that the shape of the dus and sachet is easier in the storage so it is more practical. Soy sachet sauce is enough to meet the needs of family members in a single use. In addition. soy sachets packaging can be immediately discarded without the necessity to prepare a place for its storage. Packaging is very effective to encourage consumers to buy a product. packaging can form a solid product image. durable or durable so that consumers will choose the product in accordance with the usage needs (Yulianti and Dewi 2011).

The perception of availability in this study is the ease to obtain the desired product. Almost all individuals in urban $(98.60 \%)$ and rural $(97.30 \%)$ stated that soy sachets are more easily found around the residence. This can be caused in the vicinity of individual residences. there are stalls that provide soy sachets packaging. Sumarwan (2011) states that a location far from consumers will not be desirable to visit. Effandi's research (2010) stated that traditional retailers in both urban and rural areas are directly proportional to the population. The more the population. the more traditional shops are. Therefore. it can be concluded that there will be traditional merchant retailers both in rural and urban areas that tend to be close to shopping centers.

Risk perception is an uncertainty faced by consumers when they can not foresee the impact of their purchasing decisions (Solomon 2001). In this research the risk is sachet garbage packaging against environmental damage. The percentage of individuals in urban and rural areas. in which they declare that plastic waste is not dangerous to the environment is greater than individuals who claim that it is dangerous to the environment. This is due to individual ignorance of the dangers of plastic waste to the environment. presumably due to the relatively low level of individual education. According to Riswan et al. (2011) in his research on household waste management. It was stated that the level of education is positively related to household waste management. This means that the higher level of household education. the better waste management will be. While the results of the research level of education is low.

Table 2 Positive and negative individual perceptions of the sachet packaging. average. minimum value. maximal score. standard deviation. and individual perception difference test by region

\begin{tabular}{|c|c|c|c|c|c|c|c|c|c|}
\hline \multirow{2}{*}{$\begin{array}{l}\text { Perception } \\
\text { Category }\end{array}$} & \multicolumn{4}{|c|}{ Urban } & \multicolumn{4}{|c|}{ Rural } & \multirow{2}{*}{$\begin{array}{c}p- \\
\text { value }\end{array}$} \\
\hline & Mean & Stdev & Min & Max & Mean & Stdev & Min & Max & \\
\hline Price & 60.96 & 18.05 & 33.33 & 100.00 & 67.34 & 16.19 & 33.33 & 100.00 & $0.025^{*}$ \\
\hline Usage & 63.01 & 10.11 & 44.44 & 88.89 & 60.96 & 8.27 & 38.89 & 77.78 & 0.180 \\
\hline Availability & 84.47 & 17.64 & 33.33 & 100.00 & 85.14 & 18.42 & 33.33 & 100.00 & 0.825 \\
\hline Risk & 38.05 & 13.47 & 0.00 & 66.67 & 38.89 & 15.85 & 0.00 & 77.78 & 0.731 \\
\hline
\end{tabular}


Individuals in urban and rural areas have a positive perception of price perceptions. usage. and availability. whereas individual perceptions of the risk of sachet packaging are negative. Positive price perception means that the price of sachet packaging is in accordance with individual expectations. Hopefully this can be assumed that the price of sachet packaging is cheap. A positive usage perception means the usefulness of sachet packaging in accordance with individual expectations. the expectation can be expected that the sachet packaging is practically usable. A positive availability perception means that the availability of sachet packaging is exactly like what has been expected. The expectation is that it is easy to get around the dwelling. Negative risk perception means that the risk of sachet packaging does not match the expectations of the individual. His expectation can be assumed that sachet packaging is dangerous to the environment (Table 2).

Based on the statistical test it is known that there are significant differences in the perception of rural and urban individuals on price perceptions (Table 2). this is because the perception of rural individuals has a higher rate than that of individuals in urban areas. This means that individuals in rural areas perceive sachet packaging price which is cheaper than individuals in urban areas. According to Sumarwan (2011) a consumer will possess different levels of sensation. The sensitivity difference between individuals occurs because the ability of receptors between individuals is not the same. This causes the perception of each individual different.

\section{Purchase Behavior and Decision of Soy Package Sachet In Urban and Rural Area}

\section{Packaging Type}

Types of packaging and the volume of soy sauce consumed by individuals vary. Some urban respondents (17.80\%) and rural (29.72\%) consume soy sachets. but the largest proportion of individuals consumes small refill packaging soy sauce. Chi-square test results showed that there are significant differences in the type of soy sauce consumed in urban and rural areas. Individuals in urban areas are more varied in buying packaging and volume of soy sauce. while rural individuals tend to buy soy sachets and small plastic refill types than other types of soy sauce.

\section{Frequency}

Based on the results of the Independent sample t-test there is a significant difference in the frequency of soy sauce purchases in urban and rural areas. This is because urban individuals choose to buy soy packaging refill for a long use. While 23.00 percent of rural individuals buys soy sauce every day or when they want to onsume it. However. the largest proportion of the frequency of soy sauce purchases in urban and rural areas is 1 to 2 times per week.

\section{Spending}

Average spending on soy sauce in rural areas is greater than in urban areas. But. based on the Independent sample t-test. packaging expenditure in urban and rural areas did not differ significantly. The number of ketchup expenditure depends on the type of packaging purchased and the frequency of purchase. The 
average frequency of soy sauce purchase in rural areas is more frequent than that in urban areas so that the soy sauce expenditure will be greater.

\section{Place of Purchase}

Based on Chi-square test results there were significant differences in the purchase of soy sauce in urban and rural areas. The place for the purchase of soy sauce in the countryside was mostly done in the stalls around the house. This was because the research location was far from shopping centers. such as markets and supermarkets. In addition. there was no public transport to the highway so that individuals who do not own a private vehicle choose a shopping place that can be reached on foot.

The place for the purchase of soy sauce in urban areas was more varied. The residence of the urban community was relatively close to the shopping center of Anyar Market. self-service which can be reached on foot. The availability of various types of soy packaging influences the decision of household purchases on soy products (Dewi et al.. 2013).

\section{Buying decision}

Individual purchase decisions on soy sauce packaging are divided into two. namely buying sauce packaging sachet and not buying soy sachets packaging. Chi-square test results showed that there was no significant difference in the purchase decision of soy sauce in urban and rural packaging. Individuals in rural areas bought more soy sachets $(29.73 \%)$ than those in urban areas $(17.81 \%)$. Based on Sy-Changco and Pornpitakpan (2011) research. Indian rural communities have low incomes and very limited storage areas. so people prefer sachet sized packaging products in product purchases.

\section{Reasons for Purchasing}

There are four reasons why many urban individuals choose to buy soy sachets. that is. sachet. cheap. practical. easy to get around the place of residence. and the price which is affordable.

There are five reasons that many individuals choose in rural areas - cheap. practical. easy to store. easy to get around. and prices in accordance with purchasing power. In the study of Satyajaya et al. (2014) on the purchase of sachet packaged coffee. the main reason why individuals buy sachet packaging products is because of the availability of products. affordable prices. and good taste. There are two statements that are not the reason in deciding the purchase of soy sachets packaging in urban and rural in a sequence that looks interesting friendly. Individuals in urban areas are not too concerned about the look of the packaging. This can be because individuals do not consume various brands of soy sauce. They are just loyal with one brand of soy sauce that suits their own tastes and family. Individuals in the countryside are accustomed to shopping according to personal taste. 


\section{The relationship of Individual and Family Characteristics with Sachet Packaging Perception}

The correlation test results showed that the individual residence area had a significant positive relationship with the perception of the price $(\mathrm{r}=0.184 . \mathrm{p}=$ 0.025). This suggests that individuals in urban areas get more exposure to the price of various types of soy sauce packaging. from sauce to soy sauce packaging to large packaging soy sauce. This is due to urban areas which are closer to shopping centers. such as. stalls. markets. and supermarkets. So the perception of the price was higher. meaning the individual has the perception that the price of sachet packaging is cheaper than other packaging sizes. According to Sumarwan (2011). the residence of a consumer will affect his consumption patterns. Consumers who live in the village have limited access to a variety of products and services. while consumers living in the city can obtain various goods and services needed more easily.

Table 3 Relationship of individual and family characteristics with perceptions of sachet packaging

\begin{tabular}{lcccc}
\hline Variable & $\begin{array}{c}\text { Perseption } \\
\text { of price }\end{array}$ & $\begin{array}{c}\text { Perseption } \\
\text { of usage }\end{array}$ & $\begin{array}{c}\text { Perseption of } \\
\text { availability }\end{array}$ & $\begin{array}{c}\text { Perseption } \\
\text { of risk }\end{array}$ \\
\hline Area(1=rural; 0=urban) & $0.184^{*}$ & -0.111 & 0.018 & 0.029 \\
Age (year) & -0.029 & -0.053 & -0.088 & 0.042 \\
Lenght of education (year) & -0.151 & -0.009 & 0.012 & -0.114 \\
Work (0= unwork; 1=work) & 0.106 & -0.046 & -0.029 & 0.060 \\
Number of family member & -0.098 & 0.012 & -0.017 & -0.006 \\
(person) & & & 0.017 & -0.060 \\
Per capita income (IDR & -0.001 & 0.106 & \\
000/month) & & & \\
Explanation : $*$ ) significant at p-value $<0.05 ; * *)$ significant at p-value $<0.01$ &
\end{tabular}

\section{Influence of Perception on Purchase Decision Ketchup Sachet Packaging}

\section{Urban Area}

Logistic regression tests were performed on individual characteristics. family characteristics. and perceptions of purchasing decisions on soy sauce packaging. The results of the test indicated that in urban areas the number of family member has significantly negative effect to the decision of purchasing the soy sache packaging with odds ratio of 0.33 . This showed that individuals who have fewer family members have an opportunity to decide to buy ketchup sack as many as 0.33 times compared to individuals who have many family members. The fewer the family members. the less soy sauce is consumed. However. the more the family members. the more soy sauce is consumed. This is in accordance with the results of research Patel and Bhaat (2015) that the number of family members affect the purchase decision. Consumers with a large number of family members will decide to buy a large size product. while a small number of family members will encourage small-size product purchase decisions. 
Table 4 Influence of individual characteristics. family characteristics. and perceptions on purchasing decision of soy sauce in urban packaging

\begin{tabular}{|c|c|c|c|}
\hline Independent variable & $\mathrm{B}$ & $\operatorname{Exp}(B)$ & Sig. \\
\hline Constant & & 7.398 & 0.669 \\
\hline Age (year) & -0.047 & 0.954 & 0.179 \\
\hline Lenght of education (year) & 0.039 & 1.039 & 0.804 \\
\hline Employment (0: unwork; 1: work) & 0.418 & 1.519 & 0.650 \\
\hline Number of family member (person) & -1.101 & 0.332 & $0.004 * *$ \\
\hline Per capita income (IDR 000/month) & 0.000 & 1.000 & 0.421 \\
\hline Perception of price & 0.076 & 1.079 & $0.017 *$ \\
\hline Perception of usage & 0.010 & 1.010 & 0.822 \\
\hline Perception of availability & -0.020 & 0.980 & 0.378 \\
\hline Perception of risk & -0.045 & 0.956 & 0.215 \\
\hline Chi-square & \multicolumn{3}{|c|}{22.303} \\
\hline $\mathrm{R}^{2}$ Nagelkerke & \multicolumn{3}{|c|}{0.433} \\
\hline Sig & \multicolumn{3}{|c|}{0.008} \\
\hline
\end{tabular}

Explanation : *) significant at $\mathrm{p}$-value $<0.05 ; * *)$ significant at $\mathrm{p}$-value $<0.01$

In addition. price perceptions have a significantly positive effect on the purchase decision of soy sachets packaging with odds ratio of 1.08. This showed that individuals who have positive price perceptions have a chance of 1.08 times to decide on sachets to buy soy sauce instead of individuals who do not have a positive price perception. The results of this study is in accordance with the results of research Samosir and Prayoga (2015) stating that the perception of the price positively affect the decision to purchase the product. The urban area is close to the shopping center. in which individuals can find a wide selection of types of ketchup packs at varying prices. Thus allowing individuals to compare the price of each type of soy sauce packing and buy the soy sauce according to their purchasing power. In addition. individuals are free to choose where they like to shop.

The value of $\mathrm{R}^{2}$ Nagelkerke is 0.43 which means that 43.00 percent of the purchase decision of soy sauce packaging sachet is influenced by the independent variables studied. the remaining 57.00 percent influenced by other unrelated free variables such as. product attributes. color. taste. and packaging (Soegiono 2010).

\section{Urban Area}

Logistic regression tests were performed between individual characteristics. family characteristics. and perceptions of purchasing decisions of soy sachets. The results of tests conducted in rural areas showed that there were no independent variables that significantly influence the purchase decision of soy sachets packaging. The results of the test in accordance with research Maulinda and Simatupang (2010) that consumer perceptions have no effect on product purchasing decisions. Rural areas are far from shopping centers. causing individuals not to be exposed to various types of soy sauce and price packs. due to the limitations of products sold around the dwelling. Therefore. the individual is limited in comparing the price of each type of soy sauce packing. In addition. the choice of places to shop is limited so that inevitably individuals buy the type of ketchup packaging that is available in the stalls around the house. 


\section{Urban and Rural Areas}

The result of logistic regression test of individual characteristic. family characteristic. and perception on purchase decision of ketchup of sachet packaging showed that price perception had a significantly positive effect on purchase decision of soy sauce packaging with odds ratio of 1.04. This shows that individuals who have a high price perception have the opportunity to decide to buy soy sauce packaging sack 1.04 times. compared to individuals who do not have high price perception. This means that individuals in urban and rural areas decide to purchase soy sachets just because the price is cheap.

The value of $\mathrm{R}^{2}$ Nagelkerke is 0.21 . which means that 21.00 percent of the purchase decision of soy sauce packaging sachet is influenced by independent variables studied. The remaining 79.00 percent is influenced by other independent variables that are not examined such as product attributes. color. taste. and packaging Soegiono 2010). The results of this study in accordance with the results of research Samosir and Prayoga (2015) stating that the perception of the price positively affect the decision to purchase the product.

Limitations in this study is not to examine all the processes of the purchase decision that is the introduction of needs. information search. alternative evaluation. determine alternative options. and determine the choice of products. Researchers only examine the process of making choices. especially buying or not buying ketchup packaging sachet.

Table 5 The influence of individual characteristics. family characteristics. and perceptions on purchasing decision of soy sauce in urban and rural packaging

\begin{tabular}{|c|c|c|c|}
\hline Independent Variable & $\mathrm{B}$ & $\operatorname{Exp}(B)$ & Sig. \\
\hline Constant & -0.594 & 0.552 & 0.743 \\
\hline Area $(1=$ urban; $0=$ rural $)$ & 0.169 & 1.184 & 0.743 \\
\hline Age (year) & -0.024 & 0.976 & 0.236 \\
\hline Lenght of education (year) & -0.108 & 0.897 & 0.198 \\
\hline Employment (0: unwork; 1: work) & 0.307 & 1.350 & 0.548 \\
\hline Number of family member (person) & -0.262 & 0.769 & 0.072 \\
\hline Per capita income (IDR 000/month) & 0.000 & 1.000 & 0.254 \\
\hline Perception of price & 0.036 & 1.036 & $0.012 *$ \\
\hline Perception of usage & 0.006 & 1.006 & 0.802 \\
\hline Perception of availability & 0.005 & 1.005 & 0.712 \\
\hline Perception of risk & -0.020 & 0.980 & 0.187 \\
\hline Chi-square & \multicolumn{3}{|c|}{22.484} \\
\hline $\mathrm{R}^{2}$ Nagelkerke & \multicolumn{3}{|c|}{0.213} \\
\hline Sig & \multicolumn{3}{|c|}{0.013} \\
\hline
\end{tabular}

Explanation : *) significant at $\mathrm{p}$-value $<0.05 ; * *)$ significant at $\mathrm{p}$-value $<0.01$

\section{Conclusion}

\section{Conclusion and Suggestion}

Individual perceptions of soy packaging sachet is divided into four perceptions of price. usability. availability. and risk. Individuals have a positive perception on price perceptions. usefulness. availability. and negative perceptions of risk perceptions. This is sequentially because the sachet packaging has a cheap 
price and its use is practical. Therefore. it is available around the dwelling. but unfortunately it is not environmentally friendly. Urban and rural individuals have differences in price perceptions. rural individuals are more perceptive that the price of sachet packaging is cheap. The behavior of packaging ketchup purchase in urban and rural areas differs significantly in the type of packaging and purchased volume. purchase frequency. and place of purchase. Individuals in urban areas are more varied than that in rural individuals in buying this type of ketchup packaging. as well as with the place of purchase. In addition. there are three reasons most individuals selected that allegedly influence purchasing decisions. namely low prices. prices in accordance with purchasing power. and practical use.

Individual purchasing decisions in rural areas buy more soy sachets than those living in urban. Based on correlation test results. the geographical location of urban and rural individuals is positively correlated significantly with the perceptions of the sachet packaging price. Based on the result of logistic regression test in urban area. the number of family member had significantly negative effect and price perception had a significantly positive effect on the purchase decision of soy sacheon packaging. while in the countryside there was no independent variable that had significant effect. Overall in urban and rural areas. price perceptions have a significantly positive effect on the purchase decision of soy sachets.

\section{Suggestion}

This study was conducted on the family unit on the purchase of soy sachets. and the perception of the purchase of soy sachets. Therefore. further research is advised to analyze the taste and loyalty of the sachet packaging brand of sachets for broader range of results. In addition. improving consumer knowledge about plastic packaging products by providing counseling and socialization about the advantages and disadvantages of consuming plastic packaging products in various sizes. The hope. the family is more wise in using sachet packaging products to minimize losses that may occur to the environment. For families who often consume soy sauce should buy a large size soy sauce. While families who rarely eat soy sauce should buy ketchup packaging in accordance with the needs. The price per unit of soybean volume varies. depending on the brand of soy sauce. A soy sauce brand has a cheaper price per unit of Rp22.72 / $\mathrm{ml}$ on the $22 \mathrm{ml}$ sachets soy sauce type. While the brand of soy sauce B has a cheaper price per unit. that is. Rp33.33 / $\mathrm{ml}$ on the type of small refill soy sauce. Therefore. brand A soy sauce has a price per unit of soy sauce packaging sachet is cheaper than other types of soy sauce packaging. While branded soy sauce B has a cheaper price per unit of soy sauce on a small refill packaging type. Therefore. it will be economically profitable if the family buys soy packaging. but note the impact of plastic packaging waste on the environment. 


\section{References}

BPS (Badan Pusat Statistik). (2015). Garis Kemiskinan Menurut Provinsi. 20132015. http://www.bps.go .id/linkTableDinamis/view/id/1120.

BKKBN (Badan Koordinasi Keluarga Berencana Nasional). (2011). Profil Pendataan keluarga Tahun 2010. Jakarta (ID): Direktorat Pelapor dan Statistik.

Dewi. V. R.. Yaktiworo. I.. Suriaty. S. (2013). Pengambilan keputusan rumah tangga dalam mengonsumsi kecap manis di Kota Bandar Lampung. Jurnal Agribisnis. 1(3): 1-10.

Effandi. Faris. (2010). Pola sebaran minimarket dengan kinerja usaha toko pengecer tradisional di kota kecil (Studi kasus: Kota Soreang. Tanjungsari. dan Lembang). Jurnal Perencanaan Wilayah dan Kota. 21(3):183-196.

Kariyawasan. S.. Udith. J.. Jeevika. W. (2006). Assessing consumer perceptions towards attributes of food quality: The case of consumption of tetra-packed fresh milk in Sri Lanka. [Montreal. Quebec. Canada. May 26-28]. Canada (US). hlm: 1-18. http://ageconsearch.umn.edu/handle/34173.(Prosiding)

Kittilertpaisan. J.. Chakrit. C. .(2013). Consumer perception on purchase intention towards Koa Hang: An exploratory survey in Sakon Nakhon Province. [Sanur. Bali. Nov 21-22]. Bali (ID). hlm:1-6. icebm.tarumanagara.ac. $\mathrm{id} / . . . / 26 . \% 20 \mathrm{Jitti} . \% 20 \mathrm{Chakrit} \% 20$ $\% 20$ CONSUMER\%20PERCEPTION\%20ON\% $\% 20$ I...(Prosiding)

20PURCHAS

Kotler. P.. Keller. K. L. (2016). A Framework for Marketing Management. England (UK): Pearson Education.

Leibtag. E. S.. Kaufman. P. R. (2003). Exploring food purchase behavior of lowincome households. Journal of Economic Research Service. 1-7.

Maulinda. Simatupang. (2010). Pengaruh motivasi. persepsi. dan sikap konsumen terhadap keputusan pembelian produk sirup merek value plus. JRMB. 2(5): 101-120.

Patel. D.. Bhatt. A. (2015). Influence of package size on consumer buying decision. International Journal of Multidisciplinary Research and Development. 2(3): 716-718.

Priyogutomo. J. (2011). Persepsi konsumen terhadap pengemasan produk di Indonesia dan pengaruhnya terhadap keputusan pembelian.. Yogyakarta (ID): Universitas Atma Jaya Yogyakarta.Disertasi

Pusat Data dan Sistem Informasi Pertanian. 2013. Buletin Konsumsi Pangan. 4(3): $1-54$.

Riswan. Sunoko H. R.. Hadiyarto. A. (2011). Pengelolaan sampah rumah tangga di Kecamatan Daha Selatan. Jurnal Ilmu Lingkungan. 9(1):31-39

Ruwani. Retnaningsih. Simanjuntak. M. (2014). Nilai dan tipe konsumen rumah tangga dan kaitannya dengan perilaku pembelian produk makanan kemasan. Jurnal Ilmu Keluarga dan Konsumen. 7(1): 48-57.

Sappaile. B.I. (2007). Pembobotan butir pernyataan dalam bentuk skala likert dengan pendekatan distribusi Z. Jurnal Pendidikan dan Kebudayaan Tahun ke-13. 1(64): 1-8.

Samosir. C.. Prayoga. A. (2015). Pengauh persepsi harga dan promosi terhadap keputusan pembelian konsumen produk Enervon-C. Jurnal Ilmiah Manajemen dan Bisnis. 1(3): 1-13. 
Satyajaya. W.. Rangga. A.. Nurainy. F.. Rayid. H. L. (2014). Proses pengambilan keputusan konsumen dan atribut produk kopi instan dalam sachet. Jurnal Teknologi Industri dan Hasil Pertanian. 19(2): 297-306.

Schiffman. L. G.. Kanuk. L. L. (2008). Perilaku Konsumen. Zoelkifli K. penerjemah; Bambang S. editor. Jakarta (ID): PT Indeks. Terjemahan dari: Consumer Behaviour. Seventh Edition.

Sebataraja. L. R.. Oenzil. F.. Asterina. (2014). Hubungan status gizi dengan status sosial ekonomi keluarga murid sekolah dasar di daerah pusat dan pinggiran Kota Padang. Jurnal Kesehatan Andalas. 3(2):182-187.

Setiadi. N. (2010). Perilaku Konsumen. Jakarta (ID): Kencana.

Soegiono. F. (2012). Impor vs lokal: Studi kasus tentang keputusan membeli makanan kemasan. Jurnal Ilmiah Mahasiswa Universitas Surabaya. 1(1): 110.

Solomon. M. R. (2002). Consumer Behaviour. New Jersey (US): Prentice-Hall.

Sugiyanto. F. S.. Sucipto. Asmaul. S. (2014). Analisis keterkaitan antara atribut kemasan teh celup dan etnik terhadap kepuasan konsumen. skripsitipftp.staff.ub.ac.id/files/.../5.-JURNAL-Firda-Suci-Sugiyanto.pdf

Sukma. N.. Baihaqi. A. (2013). Analisis persepsi terhadap produk cokelat di Kota Banda Aceh. Jurnal Agrisep. 14(2): 54-64.

Sumarwan. U. (2011). Perilaku Konsumen Teori dan Penerapannya dalam Pemasaran. Bogor (ID): Ghalia Indonesia.

.. Puspitawati. H.. Hariadi. A.. Ali. M. M.. Gazali. M.. Hartono. S.. \& Tara. F. (2013). Riset Pemasaran dan Konsumen [Research of Marketing and Consumer] (3rd ed.). Bogor. Indonesia: IPB Press.

Sy-Changco. J.. A.. Pornpitakpan. C. (2011). Managerial insights into sachet marketing strategies and popularity in the Philippines. Asia Pacific Journal of Marketing and Logistics. 23(5): 755-772.

Yulianti. Dewi. Y. S. (2011). Analisis faktor kemasan bumbu masak racik yang memengaruhi minat beli konsumen di Bandung. Jurnal Integra. 1(2): 161174.

Zeithalm. V. A. (1988). Consumer perception of price. quality and value: a means-end model and synthesis of evidence. Journal of Marketing. 52: 222.

Zuhdi. S.. Denny. S. (2009). Pengaruh atribut produk terhadap persepsi konsumen. Jurnal Ilmiah Ranggagading. 9(2): 104-111. 